\title{
STATUS PENGUASAAN TANAH DI KAWASAN PANTAI DAN PESISIR YANG DIJADIKAN KAWASAN PERMUKIMAN RUMAH PELANTAR DI KABUPATEN KEPULAUAN ANAMBAS
}

\author{
Yani Pujiwati ${ }^{1}$, Amiruddin A. Dajaan Imami ${ }^{2}$, Alya Maesha ${ }^{3}$ \\ ${ }^{1}$ Dosen Fakultas Hukum Univestitas Padjadjaran \\ ${ }^{2}$ Dosen Fakultas Hukum Univestitas Padjadjaran \\ ${ }^{3}$ Mahasiswa Program S1 Fakultas Hukum Univestitas Padjadjaran
}

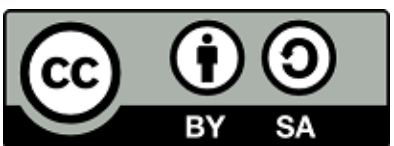

DOI: http://dx.doi.org/10.33603/hermeneutika.v3i2

Diterima: 22 Januari 2020; Direvisi: 25 Mei 2020; Dipublikasikan: Agustus 2020

\begin{abstract}
Abstrak: Kawasan pantai dan pesisir pada umumnya telah dijadikan tempat tinggal yang pada mulanya didirikan oleh para nelayan dengan alasan ingin dekat dengan sumber mata pencahariannya yakni di laut. Masyarakat Kabupaten Kepulauan Anambas menyebut tempat tinggal yang didirikan kawasan pantai dan pesisir adalah rumah pelantar. Terhadap Rumah pelantar ini terdapat permasalahan hukum yakni mengenai penguasaan tanah di kawasan pantai dan pesisir yang tidak memiliki status hukum yang jelas, bangunan tersebut hanya berdasarkan Alas Hak yang diberikan oleh Kepala Desa setempat. Tujuan penelitian ini adalah untuk mengetahui penguasaan tanah di kawasan pantai dan pesisir yang dijadikan permukiman rumah pelantar di kabupaten kepulauan anambas provinsi kepulauan riau dan mengenai status dari permukiman rumah pelantar di kawasan pantai dan pesisir yang menjamin kepastian hukum. Metode penelitian yang digunakan dalam penelitian ini adalah metode penelitian yuridis normatif yaitu menekankan pada norma hukum, dengan berdasarkan pada ketentuan peraturan perundang - undangan yang mengatur mengenai kawasan pesisir. Berdasarkan penelitian yang dilakukan dapat disimpulkan, penguasaan tanah yakni Alas Hak yang diberikan oleh Kepala Desa setempat yang dimiliki oleh masyarakat Kepulauan Anambas ini tidak sesuai dengan peraturan perundang - undangan yang berlaku. Seharusnya Permukiman Rumah Pelantar di Kawasan Pantai Dan Pesisir memilik Izin Lokasi yang diterbitkan oleh pejabat yang berwenang, bagi masyarakat lokal atau pendatang yang tidak secara turun temurun. Lalu untuk masyarakat adat atau anggota masyarakat yang secara turun-temurun sudah bertempat tinggal di kawasan pesisir dapat memiliki hak atas tanah yang diterbitkan oleh Kantor Pertanahan Kabupaten Kepulauan Anambas hal ini dilakukan sebagai upaya terciptanya kepastian hukum.
\end{abstract}

Kata kunci: Kawasan Pantai dan Pesisir, Penguasaan Tanah, Permukiman 


\section{PENDAHULUAN}

Tanah meliputi permukaan bumi yang ada di daratan dan permukaan bumi yang berada di bawah air, termasuk air laut. ${ }^{1}$ Tanah merupakan suatu hal yang penting bagi setiap individu untuk kebutuhan hidupnya, maka akan dilakukan berbagai cara untuk memenuhi kebutuhan akan tanah tersebut. Hal ini tentu dapat menimbulkan permasalahan dalam hal penguasaan tanah yang tidak menutup kemungkinan di kemudian hari akan terjadi sengketa kepemilikan tanah. Maka dari itu pada Pasal 19 ayat (1) UUPA dikatakan bahwa untuk menjamin kepastian hukum oleh pemerintah diadakan pendaftaran tanah di seluruh wilayah Republik Indonesia menurut ketentuan yang diatur dengan Peraturan Pemerintah.

Pendaftaran tanah yang dikonversi dalam bentuk sertifikat sebagai bukti authentik kepemilikan memiliki nilai ekonomis yang besar dalam masyarakat. Sertifikat dapat dikategorikan sebagai suratsurat berharga. Sertifikat sebagai wujud pemberian hak atas tanah. Pemberian hak atas tanahya itu, pemberian hak yang dikuasai langsung oleh negara kepada seseorang ataupun beberapa orang bersamasama atau sesuatu badan hukum. ${ }^{2}$

Seiring dengan peningkatan jumlah penduduk dari tahun ke tahun, penggunaan tanah untuk kebutuhan perumahan dan fasilitas-fasilitas lainnya yang terkait semakin meningkat. Oleh karena itu, peningkatan penggunaan tanah ini mengakibatkan sulitnya bagi masyarakat untuk memenuhi kebutuhannya akan perumahan atau permukiman, hal ini tidak hanya di rasakan oleh masyarakat yang tinggal di kota - kota besar saja melainkan bagi mereka yang tinggal di pulau - pulau kecil di Indonesia pun mengalami kesulitan. Laju pertumbuhan penduduk yang cukup

\footnotetext{
${ }^{1}$ Boedi Harsono, Hukum Agraria Indonesia (Sejarah pembentukan Undang-undang Pokok Agraria, Isi dan Pelaksanaannya), Jilid I, Cetakan keduabelas, Jakarta: Djambatan, 2003, Hlm. 6-7.

2 Ali Achmad Chomzah, Hukum Pertanahan, Jakarta: Prestasi Pustaka,2002, Hlm. 1.

tinggi yang mengakibatkan kebutuhan mereka akan tanah juga semakin tinggi sedangkan tanah yang tersedia terbatas untuk tempat - tempat tertentu dan telah digunakan untuk membangun rumah dan bangunan-bangunan lainnya, sehingga mereka berusaha mencari solusi untuk memenuhi kebutuhan mereka akan tanah.

Wilayah pulau yang terdiri dari pantai ini merupakan daerah yang sangat intensif dimanfaatkan untuk kegiatan manusia, seperti sebagai kawasan pusat pemerintahan, permukiman, industri, pelabuhan, pertambakan, pertanian/perikanan, pariwisata, dan sebagainya. Adanya berbagai kegiatan tersebut dapat menimbulkan peningkatan kebutuhan akan lahan, sarana dan prasarana pendukung dari masing-masing kegiatan tersebut. Wilayah pantai selain intensif terdapat juga sisi sensitifnya dikarenakan pantai merupakan kawasan lindung, oleh karena itu menjadi penting untuk diatur agar terdapat kepastian hukum.

Seperti halnya pulau pulau yang berada di Kabupaten Kepulauan Anambas Provinsi Kepulauan Riau yang terletak pada antara $2^{\circ} 10^{\prime} 0^{\prime \prime}-3^{\circ} 40^{\prime} 0^{\prime \prime}$ Lintang Utara dan $105^{\circ} 15^{\prime} 0^{\prime \prime}-106^{\circ} 45^{\prime} 0^{\prime \prime}$ Bujur Timur dengan luas wilayah daratan 590,14 $\mathrm{Km}^{2}$ dan luas lautan 46.033,81 $\mathrm{Km}^{2}{ }^{3}$ Budaya hidup penduduk di daerah tersebut sudah diturunkan sejak zaman nenek moyang mereka. Dimana mereka tinggal dan beraktivitas di atas air, mulai dari rumah berada di atas air, mata pencaharian sebagai nelayan, dan aktivitas lainnya. Hal ini tidak dapat dipungkiri oleh kita, karena secara letak Indonesia memang sebagai Negara Kepulauan. Kebiasaan masyarakat di Kabupaten Kepulauan Anambas yang bergantung pada laut dan juga permukiman warga berada di wilayah pesisir dan pantai, sehingga apabila melihat banyak tempat tinggal dan tempat usaha yang berada di

\footnotetext{
3 Pasal 3 Ayat (1) Peraturan Daerah Kabupaten Kepulauan Anambas Nomor 3 Tahun 2013 Tentang Rencana Tata Ruang Wilayah Kabupaten Kepulauan Anambas Tahun 2011-2031.
} 
wilayah pesisir dan pantai merupakan hal yang biasa bagi masyarakat di Kabupaten Kepulauan Anambas.

Masyarakat Anambas memanfaatkan wilayah pantai dan pesisir untuk membangun tempat tinggal dan tempat usaha namun ada beberapa desa yang dalam penguasaan tanah atau ruang di kawasan pantai dan pesisir ini tidak memiliki status hukum yang jelas, mereka mendirikan bangunan hanya berdasarkan "Alas Hak" yang diberikan oleh Kepala Desa setempat dan di tandatangani oleh Kepala Desa dengan sepengatahuan camat dan membayar uang tunai untuk dapat mendirikan tempat tinggal. Hal ini terjadi di beberapa Desa di Kabupaten Kepulauan Anambas yaitu Desa Tarempa Timur, Desa Pesisir Timur dan Desa Temburun yang terletak di Kecamatan Siantan. Dan juga bagi masyarakat asli yang sudah turun temurun menetap di rumah pelantar sekitar Kecamatan Siantan bagi mereka sudah ada yang diberikan sertifikat hak milik yang di terbitkan oleh Kantor Pertanahan Kabupaten Kepulauan Anambas yang didasarkan "Surat Geran" atau biasa dikenal dengan Girik. ${ }^{4}$

Legalitas terhadap penguasaan tanah ini akan di pertanyakan karena dapat menimbulkan sengketa dan juga tidak ada kekuatan hukum terhadap alas hak tersebut sehingga sewaktu - waktu dapat saja terjadi penggusuran terhadap permukiman (rumah pelantar) masyarakat Anambas yang hanya berdasarkan "Alas Hak" yang diberikan oleh Kepala Desa dan tidak memiliki dasar yang kuat untuk tetap mempertahankan penguasaan tanah di wilayah pesisir tersebut.

Penguasaan tanah di wilayah pesisir diperbolehkan menurut perundang-

4 Hasil Wawancara dengan Kepala Sub Bidang Pengembangan, Evaluasi Dan Pelaporan Di Badan Penelitian Pengembangan Dan Perencanaan Daerah Kapubaten Kepulauan Anambas, Bapak Ika Rio Saputra, Pada tanggal 11 Mei 2019. undangan yang berlaku. Lahirnya Undangundang Nomor 27 Tahun 2007 tentang Pengelolaan Wilayah Pesisir dan PulauPulau Kecil yang pada perkembangannya diganti dengan Undang-undang Nomor 1 Tahun 2014 tentang Perubahan Atas Undang-undang Nomor 27 Tahun 2007 tentang Wilayah Pesisir dan Pulau-Pulau Kecil untuk selanjutnya disebut Undangundang Nomor 1 Tahun 2014 lebih memberikan jaminan kepastian hukum bagi orang-orang yang hidup diwilayah pesisir dan pantai.

Undang-undang Nomor 1 Tahun 2014 Pasal 1 angka 2 mendefinisikan wilayah pesisir sebagai daerah peralihan antara ekosistem darat dan laut yang dipengaruhi oleh perubahan di darat dan laut. Pasal 2 menyebutkan bahwa ruang lingkup pengaturan wilayah pesisir dan pulau-pulau kecil meliputi daerah peralihan antara ekosistem darat dan laut yang dipengaruhi oleh perubahan di darat dan laut, ke arah darat mencakup wilayah administrasi kecamatan dan ke arah laut sejauh 12 (dua belas) mil laut di ukur dari garis pantai. Sesuai dengan definisi wilayah pesisir pada Pasal 1 angka 2 Undangundang Nomor 1 Tahun 2014 Rumah Rumah Pelantar yang di dirikan masyarakat Kabupaten Kepulauan Anambas termasuk cakupan wilayah pesisir ke arah laut sejauh 12 (dua belas) mil laut di ukur dari garis pantai.

\section{METODE PENELITIAN}

Metode Penelitian yang dilakukan peneliti adalah metode penelitian yuridis normatif, yaitu satu metode hukum yang dilakukan dengan meneliti bahan pustaka atau data sekunder. ${ }^{5}$ Metode ini juga dilakukan dengan penafsiran hukum dan

\footnotetext{
5 Soerjono Soekanto dan Sri Mamuji, Penelitian Hukum Normatif (Suatu Tinjauan Singkat), Jakarta: Rajawali Pers, 2001, Hlm. 13-14.
} 
konstruksi $\quad$ hukum. $^{6}$ Dengan menitikberatkan pada bahan - bahan hukum primer, bahan - bahan hukum sekunder baik berupa peraturan perundang - undangan dan buku - buku tentang hukum tanah, permukiman maupun kawasan pesisir serta bahan hukum tertier (hasil-hasil penelitian, pengkajian, sumber internet dan sebagainya). ${ }^{7}$

Bahan hukum primer antara lain berupa Undang - Undang Dasar Republik Indonesia 1945, Undang-Undang Nomor 5 Tahun 1960 tentang Peraturan Dasar PokokPokok Agraria, Undang-Undang Nomor 26 Tahun 2007 tentang Penataan Ruang, Undang-Undang Nomor 32 Tahun 2009 tentang Perlindungan dan Pengelolaan Lingkungan Hidup, Undang - Undang Nomor 1 Tahun 2011 tentang Perumahan dan Kawasan Pemukiman, Undang-Undang Nomor 1 Tahun 2014 tentang Perubahan atas Undang-Undang Nomor 27 Tahun 2007 tentang Pengelolaan Wilayah Pesisir dan Pulau-Pulau Kecil, Peraturan Menteri Agraria dan Tata Ruang/Kepala Badan Pertanahan Nasional Nomor 17 Tahun 2016 tentang Penataan Pertanahan di Wilayah Pesisir dan Pulau-Pulau Kecil, Peraturan Menteri Kelautan Dan Perikanan Republik Indonesia Nomor 24/Permen-Kp/2019 Tentang Tata Cara Pemberian Izin Lokasi Perairan Dan Izin Pengelolaan Perairan Di Wilayah Pesisir Dan Pulau-Pulau Kecil , Peraturan Daerah Kabupaten Kepulauan Anambas Nomor 3 Tahun 2013 Tentang Rencana Tata Ruang Wilayah Kabupaten Kepulauan Anambas Tahun 2011-2031. Bahan hukum sekunder berupa literaturliteratur, buku-buku hasil karangan para ahli, jurnal ilmiah, artikel-artikel, karya ilmiah, dan tulisan lainnya khususnya yang terkait dengan obyek penelitian. Bahan hukum tersier berupa kamus baik kamus

${ }^{6}$ Sunaryati Hartono, Penelitian Hukum di Indonesia Pada Akhir Abad Ke - 20, Bandung: Alumni, 2006, Hlm. 139.

7 Ronny Hanityo Soemitro, Metodologi Penelitian Hukum dan Jurimetri, Jakarta: Ghalia Indonesia, 2000, Hlm. 1-2. terjemahan maupun kamus hukum, ensiklopedia, dan sebagainya.

Metode analisis data dilakukan secara normatif kualitatif, yaitu dengan cara menginventarisir, menyusunnya dengan secara sistematis, menghubungkannya satu sama lain terkait dengan permasalahan yang diteliti dengan berlakunya ketentuan peraturan perundang - undangan yang satu tidak bertentangan dengan peraturan perundang - undangan yang lain, memperhatikan hierarki perundang undangan dan menjamin kepastian hukumnya, artinya perundang - undangan yang berlaku dilaksanakan oleh penegak hukum sehingga dapat ditarik kesimpulan. ${ }^{8}$ Dengan demikian untuk mencapai kejelasan masalah yang dibahas menggunakan analisis data yang dilakukan tanpa menggunakan rumus dan angka.

\section{HASIL PENELITIAN}

\section{A. Penguasaan Tanah Kawasan Pantai dan Pesisir yang Dijadikan Permukiman Rumah Pelantar}

Masyarakat yang tinggal di daerah pulau dimana sebagian besar wilayahnya terdiri dari perairan pada umumnya memilih untuk membangun tempat tinggal di kawasan pantai dan pesisir yang kemudian akan membentuk sebuah permukiman. Pesisir dan pantai memiliki peran penting bagi masyarakat yang hidup di wilayah perairan, karena masyarakat melakukan segala aktivitas untuk kebutuhannya sehari - hari dilakukan di atas laut dan juga memanfaatkan sumber daya alam yang ada di wilayah tersebut. Berbagai aktivitas baik sosial maupun ekonomi membutuhkan lokasi pantai dan pesisir seperti membangun tempat usaha dan Kantor - Kantor Desa juga dibangun di atas perairan.

Wilayah pesisir merupakan daerah peralihan antara ekosistem darat dan laut yang dipengaruhi oleh perubahan di darat dan di laut. Wilayah pesisir mencakup daerah ke bagian laut ke arah laut sejauh 12 (dua belas) mil laut di ukur dari garis pantai

\footnotetext{
${ }^{8}$ Soejono Soekanto dan Sri Mamuji, Op.cit., Hlm. 12
} 
yang masih dipengaruhi oleh proses alam yang terjadi di darat maupun yang timbul akibat kegiatan manusia di darat yang dapat mencemari lingkungan laut, dan ke arah bagian darat dari garis pantai yang masih terdapat kantor instansi pemerintahan dan permukiman warga yang dimana masih terpengaruhi sifat - sifat laut seperti pasang surut air laut.

Pantai merupakan bagian daratan yang berbatasan dengan air laut pada waktu air pasang surut yang terendah. sedangkan pesisir adalah bagian daratan antara batas air laut pada waktu pasang surut yang terendah dan pasang naik yang tertinggi. Biarpun ada kemungkinan sudah dihaki, tetapi pesisir menurut hukumnya harus terbuka bagi umum. ${ }^{9}$

Kawasan pantai dan pesisir pada dasarnya dikuasai oleh negara yang berarti peruntukannya seharusnya juga ditujukan untuk publik atau umum maka dalam pengelolaan wilayah pesisir dan pantai diperlukan pengoordinasian perencanaan, pemanfaatan, pengawasan, dan pengendalian sumber daya pesisir dan pantai yang dilakukan oleh Pemerintah dan Pemerintah Daerah, antarsektor, antara ekosistem darat dan laut, serta antara ilmu pengetahuan dan manajemen untuk meningkatkan kesejahteraan rakyat.

Pemerintah pusat dan pemerintah daerah perlu mengembangkan komitmen yang tinggi dalam menegakkan peraturan untuk wilayah pesisir dan pantai agar tidak rusak karena ketidaktahuan atau ketidaksengajaan. Pemerintah pusat dan pemerintah daerah dapat menetapkan bahwa kegiatan yang berlokasi di kawasan itu harus memenuhi persyaratan yang sudah ditentukan dalam peraturan.

Pemanfaatan kawasan pantai dan pesisir untuk pembangunan tentunya tidak terlepas dari status penguasaan dari tanah pada kawasan tersebut yang pada umumnya

${ }^{9}$ Boedi Harsono, Op.Cit, Hlm. 284. dimanfaatkan untuk tempat tinggal, untuk tanah yang berada di daratan yang tidak dipengaruhi oleh pasang surut air laut sudah memiliki dasar hukum yang jelas mengenai status penguasaan tanah yang dapat dimiliki karena telah diatur oleh UUPA dan peraturan perundang - undangan lainnya yang terkait. Sedangkan hal ini tentunya berbeda dengan tanah di kawasan pantai dan pesisir yang tentunya terpengaruhi oleh pasang surut air laut sehingga dapat bergerak secara tidak terduga yang tentunya menimbulkan ketidakpastian akan tanah tersebut, UUPA pun tidak mengatur secara spesifik mengenai status penguasaan tanah di kawasan pantai dan pesisir.

Penguasaan tanah di kawasan pantai dan pesisir dilakukan di salah satu wilayah Indonesia yakni di Desa Pesisir Timur, Kecamatan Siantan, Kabupaten Kepulauan Anambas yaitu di kawasan pantai dan pesisirnya terdapat pembangunan untuk kepentingan pribadi yang digunakan untuk tempat tinggal dengan membangun pondasi rumah di kawasan pantai dan pesisir yang disebut dengan rumah pelantar. Permukiman Rumah Pelantar Di Desa Pesisir Timur ini pada umumnya telah ditempati oleh masyarakat dalam jangka waktu lama dan juga sudah turun temurun namun ada juga masyarakat pendatang. Awal mula didirikan rumah pelantar ini karena mata pencaharian dari masyarakat Desa Pesisir Timur adalah Nelayan sehingga mereka membuat tempat tinggal di kawasan pantai dan pesisir alasannya untuk lebih dekat dengan pompong atau sampannya (Perahu) yang menjadi sumber mata pencahariannya karena rumah pelantar ini biasanya memiliki dermaga/tambatan perahu.

Status penguasaan tanah yang dimiliki oleh penduduk Desa Pesisir Timur yang membangun rumah pelantar di daerah pesisir dan pantai berupa "Alas Hak" atau Surat Keterangan Riwayat Pemilikan Penguasaan Penggunaan Tanah yang 
diterbitkan oleh Kantor Desa yang kemudian ditandatangani oleh Kepala Desa.

"Alas Hak" yang diterbitkan atau dikeluarkan oleh Kantor Desa Pesisir Timur ini tidak memiliki dasar hukum yang jelas sehingga akibatnya surat keterangan penguasaan tanah tersebut tidak sah karena seharusnya "alas hak" atas tanah hanya dapat diterbitkan atau dikeluarkan oleh Kantor Wilayah Badan Pertanahan Nasional (Provinsi) dan kemudian didaftarkan ke Kantor Pertanahan setempat (Kota/Kabupaten). Seorang Kepala Desa tidak memiliki wewenang mengeluarkan "alas hak" dalam bentuk apapun karena itu telah melampaui kewenangan yang dimilikinya sehingga "alas hak" yang dimiliki oleh warga Desa Pesisir Timur untuk membangun rumah pelantar di kawasan pantai dan pesisir tidak sah, hal ini berdasarkan Pasal 26 Ayat (2) UndangUndang Republik Indonesia Nomor 6 Tahun 2014 Tentang Desa, yang menyatakan:

"Dalam melaksanakan tugas sebagaimana dimaksud pada ayat (1), Kepala Desa berwenang:

a. memimpin penyelenggaraan Pemerintahan Desa;

b. mengangkat dan memberhentikan perangkat Desa;

c. memegang kekuasaan pengelolaan Keuangan dan Aset Desa;

d. menetapkan Peraturan Desa;

e. menetapkan Anggaran Pendapatan dan Belanja Desa;

f. membina kehidupan masyarakat Desa;

g. membina ketenteraman dan ketertiban masyarakat Desa;

h. membina dan meningkatkan perekonomian Desa serta mengintegrasikannya agar mencapai perekonomian skala produktif untuk sebesar-besarnya kemakmuran masyarakat Desa;

i. mengembangkan sumber pendapatan Desa;

j. mengusulkan dan menerima pelimpahan sebagian kekayaan negara guna meningkatkan kesejahteraan masyarakat Desa; k. mengembangkan kehidupan sosial budaya masyarakat Desa;

1. memanfaatkan teknologi tepat guna;

m. mengoordinasikan Pembangunan Desa secara partisipatif;

n. mewakili Desa di dalam dan di luar pengadilan atau menunjuk kuasa hukum untuk mewakilinya sesuai dengan ketentuan peraturan perundangundangan."

Surat Keterangan Riwayat Pemilikan Penguasaan Penggunaan Tanah yang dikeluarkan oleh Kantor Desa sudah melampaui batas kewenangan yang dimilikinya. Surat bukti penguasaan tanah dalam bentuk apapun akan lebih baik bila langsung dikeluarkan oleh Badan Pertanahan Nasional melalui Kantor Pertanahan sehingga memiliki kekuatan hukum yang jelas dan mencegah terjadinya di kemudian hari.

Jika mengacu pada Pasal 16 Undang undang Nomor 1 Tahun 2014 dinyatakan bahwa:

"Setiap Orang yang melakukan pemanfaatan ruang dari sebagian Perairan Pesisir dan pemanfaatan sebagian pulau-pulau kecil secara menetap wajib memiliki Izin Lokasi."

Berdasarkan peraturan tersebut seharusnya masyarakat Desa Pesisir timur yang memanfaatkan ruang dari perairan pesisir seharusnya diterbitkan Izin Lokasi. Izin lokasi diberikan untuk memanfaatkan ruang secara menetap dari sebagian perairan pesisir yang mencakup permukaan laut dan kolom air sampai dengan permukaan dasar laut yang diberikan dengan luasan dan waktu tertentu serta diberikan kepada masyarakat lokal dan masyarakat tradisional yang melakukan pemanfaatan pesisir untuk pemenuhan kebutuhan hidup sehari - hari.

Berdasarkan hasil penelitian di Desa Pesisir Timur masyarakat yang membangun rumah pelantar tersebut termasuk dalam golongan Masyarakat lokal dan ada juga masyarakat tradisional hanya saja lebih di dominasi oleh masyarakat tradisional. 
Dikatakan sebagai Masyarakat lokal karena mereka menjalankan kehidupan sehari hari berdasarkan kebiasaan yang sudah diterima sebagai nilai-nilai yang berlaku umum, namun tidak sepenuhnya bergantung pada sumber daya alam pesisir dikarenakan ada masyarakat yang hanya bertempat tinggal di pesisir namun mata pencahariannya bukan merupakan nelayan. Sedangkan masyarakat tradisional mereka adalah yang bermata pencaharian sebagai nelayan karena masih diakui hak tradisionalnya dalam melakukan kegiatan penangkapan ikan atau kegiatan lainnya yang sah di daerah tertentu yang berada dalam perairan kepulauan.

Pemberian izin lokasi kepada masyarakat lokal yang memanfaatkan ruang pesisir untuk tempat tinggal dipertegas pada Pasal 45 ayat (1) Peraturan Menteri Kelautan Dan Perikanan Republik Indonesia Nomor 24/Permen-Kp/2019 Tentang Tata Cara Pemberian Izin Lokasi Perairan Dan Izin Pengelolaan Perairan Di Wilayah Pesisir Dan Pulau-Pulau Kecil:

"Fasilitasi pemberian Izin Lokasi Perairan untuk Masyarakat Lokal pada kegiatan:

a. perikanan tangkap dengan alat penangkapan ikan statis;

b. perikanan budidaya menetap;

c. wisata Bahari; dan

d. permukiman di atas air."

Menteri atau gubernur sesuai dengan kewenangannya memfasilitasi pemberian Izin Lokasi Perairan kepada Masyarakat Lokal untuk kegiatan dan permukiman di atas air sesuai dengan penetapan oleh Bupati atau Walikota yang juga berdasarkan hasil identifikasi Masyarakat Lokal yang disampaikan oleh lurah/kepala desa melalui camat.

Menteri atau gubernur sesuai dengan kewenangannya memfasilitasi pemberian Izin Lokasi Perairan kepada Masyarakat
Lokal untuk kegiatan dan permukiman di atas air sesuai dengan penetapan oleh Bupati atau Walikota yang juga berdasarkan hasil identifikasi Masyarakat Lokal yang disampaikan oleh lurah/kepala desa melalui camat lalu pemberian izin lokasi ini harus berdasarkan pada Rencana Zonasi wilayah pesisir dan pulau-pulau kecil (RZWP3K) sesuai yang diatur pada Pasal 6 ayat (3) Peraturan Menteri Kelautan Dan Perikanan Republik Indonesia Nomor 24/Permen$\mathrm{Kp} / 2019$.

Pemberian Izin Lokasi Perairan memiliki syarat yang terdapat pada Pasal 42 Peraturan Menteri Kelautan Dan Perikanan Republik Indonesia Nomor 24/Permen$\mathrm{Kp} / 2019$ yang menyatakan bahwa masyarakat lokal tersebut harus bermata pencaharian pokok sebagai nelayan dengan alat penangkapan statis atau atau memiliki penghasilan tidak lebih dari nilai rata - rata upah minimum provinsi, pembudidaya ikan atau petambak garam dan wajib berdomisili di pesisir paling singkat 5 tahun berturutturut atau paling singkat 10 tahun tidak berturut-turut.

Sedangkan berdasarkan hasil wawancara dengan Kepala Desa Pesisir Timur, bahwa rumah pelantar di Desa Pesisir Timur tidak ada yang memiliki izin lokasi bahkan Kepala Desa juga tidak mengetahui mengenai pemanfaatan ruang dari sebagian Perairan Pesisir wajib memiliki Izin Lokasi. Bagi masyarakat yang memiliki rumah pelantar tersebut hanya memiliki "Alas Hak" atau Surat Keterangan Riwayat Pemilikan Penguasaan Penggunaan Tanah. Sehingga jika mengacu pada Undang - undang Nomor 1 Tahun 2014 jo Peraturan Menteri Kelautan Dan Perikanan Republik Indonesia Nomor 24/Permen-Kp/2019 maka bukti penguasaan tanah yang dimiliki masyarakat di Desa Pesisir tidak memberikan jaminan kepastian hukum sehingga tidak dapat menjadi tanda bukti penguasaan yang kuat jika dikemudian hari terjadi sengketa. 
Disamping itu berdasarkan penelitian terdapat juga beberapa rumah pelantar yang memiliki Sertifikat Hak Milik yang diterbitkan oleh Kantor Pertanahan Kabupaten Kepulauan Anambas, yang dimana hal tersebut di dasarkan dari Alas hak yang sudah diterbitkan oleh Kepala Desa lalu dapat diajukan ke Kantor Pertanahan Kabupaten Kepulauan Anambas untuk berubah statusnya menjadi Sertifikat Hak Milik (SHM). ${ }^{10}$ Dan juga dalam pengajuan untuk mendapatkan Surat Hak Milik pemohon hak tersebut hanya perlu membuktikan bahwa rumah pelantar tersebut masih ada dan juga terdapat akses jalan menuju ke rumah tersebut serta ada pengakuan dari sempadan atau tetangga bahwa memang benar pemohon telah memiliki bangunan tersebut secara turun temurun lebih dari 30 tahun dan tidak ada sengketa kepenguasaan dari rumah pelantar tersebut.

Pemberian Sertifikat Hak Milik kepada masyarakat yang memanfaatkan kawasan pantai dan pesisir untuk dijadikan tempat tinggal tersebut sekarang sudah tidak diterbitkan lagi berdasarkan pernyataan dari Bapak Deko selaku Seksi Hubungan Hukum Pertanahan di Kantor Pertanahan Kabupaten Kepulauan Anambas hal ini karena pada dasarnya kawasan pantai dan pesisir merupakan milik negara dan tidak dapat menjadi milik pribadi dengan adanya pemberian Surat Hak Milik dan juga tidak sesuai dengan peraturan perundang undangan. Kantor Pertanahan Kabupaten Kepulauan Anambas sekarang hanya menerbitkan sertifikat berjangka waktu atau semacam Hak Guna Bangunan (HGB) ataupun Hak Pakai dengan syarat bahwa memang merupakan masyarakat lokal yang tinggal di Anambas, lalu sudah terdapat rumah pelantarnya dengan dibuktikan Alas Hak yang diterbitkan oleh Kepala Desa setempat, Sertifikat Berjangka Waktu ini memiliki jangka waktu dari 10 tahun - 30

10 Hasil wawancara dengan Kepala Desa Pesisir Timur Kecamatan Siantan Kabupaten Kepulauan Anambas, Bapak Sabli, Pada Tanggal 12 September 2019. tahun. Sebelum diterbitkan hak atas tanah, Kantor Pertanahan akan melakukan pengukuran terhadap tanah bangunan tersebut dan juga batas batas dari tanah tersebut kemudian dicatatkan dalam surat ukur tanah. ${ }^{11}$

Jika mengacu Pada Pasal 5 Ayat (1) dan (2) Peraturan Menteri Agraria dan Tata Ruang/Kepala Badan Pertanahan Nasional Nomor 17 Tahun 2016 tentang Penataan Pertanahan di Wilayah Pesisir dan PulauPulau Kecil juga menyebutkan bahwa:

“(1) Pemberian Hak Atas Tanah pada pantai hanya dapat diberikan untuk bangunan yang harus ada di Wilayah Pesisir pantai, antara lain:

a. bangunan yang digunakan untuk pertahanan dan keamanan;

b. pelabuhan atau dermaga;

c. tower penjaga keselamatan pengunjung pantai;

d. tempat tinggal masyarakat adat atau anggota masyarakat yang secara turun-temurun sudah bertempat tinggal ditempat tersebut; dan/atau

e. pembangkit tenaga listrik."

“(2) Pemberian hak atas tanah pada perairan pesisir hanya dapat diberikan untuk bangunan yang harus ada di wilayah perairan pesisir, antara lain:

a. Program strategis negara;

b. Kepentingan umum;

c. Permukiman diatas air bagi masyarakat hukum adat; dan/atau

d. Pariwisata."

Berdasarkan Peraturan Menteri Agraria dan Tata Ruang/Kepala Badan Pertanahan Nasional Nomor 17 Tahun 2016 tentang Penataan Pertanahan di Wilayah Pesisir dan Pulau-Pulau Kecil, seharusnya yang mendapatkan hak atas tanah adalah bagi permukiman diatas air yang dimiliki

\footnotetext{
${ }^{11}$ Hasil wawancara dengan Seksi Hubungan Hukum Pertanahan Di Kantor Pertanahan Kabupaten Kepulauan Anambas, Bapak Deko, Pada Tanggal 8 Oktober 2019.
} 
oleh masyarakat adat atau masyarakat yang memang sudah secara turun temurun bertempat tinggal di kawasan pantai dan pesisir tersebut namun pada pelaksanaannya tidak sesuai karena Kantor Pertanahan Kabupaten Anambas tidak mensyaratkan harus sudah tinggal dalam jangka berapa tahun atau secara turun temurun di kawasan pantai dan pesisir bagi masyarakat yang mengajukan permohonan untuk mendapatkan sertifikat berjangka waktu seperti HBG atau Hak Pakai. Sehingga masyarakat pendatang atau masyarakat lokal yang tidak tinggal secara turun temurun di kawasan pantai dan pesisir juga dapat memiliki hak atas tanah hanya dengan syarat mereka sudah membangun rumah pelantar tersebut dan didukung oleh alas hak yang diterbitkan oleh Kepala Desa.

Status penguasaan tanah di kawasan pantai dan pesisir yang dijadikan permukiman (rumah pelantar) di Kabupaten Kepulauan Anambas ini tidak sesuai dengan peraturan perundang - undangan yang berlaku karena pada Undang - undang Nomor 1 Tahun 2014 jo Peraturan Menteri Kelautan Dan Perikanan Republik Indonesia Nomor 24/Permen-Kp/2019 seharusnya terhadap masyarakat pendatang atau masyarakat lokal yang tidak turun temurun dalam memanfaatkan kawasan pantai dan pesisir untuk dijadikan tempat tinggal mereka hanya mendapatkan izin lokasi saja bukan "Alas Hak" atau Surat Keterangan Riwayat Pemilikan Penguasaan Penggunaan Tanah yang diterbitkan Kantor Desa ataupun hak atas tanah dalam bentuk Hak Milik, Hak Guna Bangunan ataupun Hak Pakai. Demikian halnya pada Peraturan Menteri Agraria dan Tata Ruang/Kepala Badan Pertanahan Nasional Nomor 17 Tahun 2016 tentang Penataan Pertanahan di Wilayah Pesisir dan Pulau-Pulau Kecil, yang mensyaratkan bahwa hak atas tanah hanya dapat diberikan pada bangunan yang merupakan tempat tinggal masyarakat adat atau anggota masyarakat yang secara turun- temurun sudah bertempat tinggal ditempat tersebut. Maka seharusnya pihak Kantor Pertanahan Kabupaten Anambas menambahkan pesyaratan untuk mendapatkan hak atas tanah agar tidak diterbitkan kepada semua pihak yang memanfaatkan kawasan pesisir untuk dijadikan permukiman pelantar.

Terhadap masyarakat Di Desa Pesisir Timur dapat dikategorikan sebagai Masyarakat Hukum Adat. Pengertian dari Masyarakat Hukum Adat adalah sekelompok orang yang secara turuntemurun bermukim di wilayah geografis tertentu di Negara Kesatuan Republik Indonesia karena adanya ikatan pada asal usul leluhur, hubungan yang kuat dengan tanah, wilayah, sumber daya alam, memiliki pranata pemerintahan adat, dan tatanan hukum adat di wilayah adatnya sesuai dengan ketentuan peraturan perundangundangan. Sebagian besar dari penduduk Desa Pesisir Timur sudah berdomisili di wilayah pantai dan pesisir sebelum adanya penetapan zonasi dan juga sudah tinggal secara turun - temurun lebih dari 30 tahun sehingga Kewajiban memiliki Izin Lokasi Perairan dikecualikan bagi Masyarakat Hukum Adat sesuai pada Pasal 67 ayat (1) Peraturan Menteri Kelautan Dan Perikanan Republik Indonesia Nomor 24/Permen$\mathrm{Kp} / 2019$. Sehingga terhadap masyarakat hukum adat Di Desa Pesisir Timur ini berhak untuk mendapatkan suatu hak atas tanah,yang juga didasarkan pada konstruksi rumah pelantar yang dibangun ini menancap dengan tanah yang berada di dasar laut dan juga statis maka dapat dikeluarkan hak atas tanah oleh Kantor Pertanahan Kabupaten Kepulauan Anambas.

Status penguasaan tanah di kawasan pantai dan pesisir yang dijadikan permukiman (rumah pelantar) di Kabupaten Kepulauan Anambas ini tidak sesuai dengan peraturan perundang - undangan yang berlaku karena pada Undang - undang Nomor 1 Tahun 2014 jo Peraturan Menteri 
Kelautan Dan Perikanan Republik Indonesia Nomor 24/Permen-Kp/2019 seharusnya terhadap masyarakat pendatang atau masyarakat lokal yang tidak turun temurun dalam memanfaatkan kawasan pantai dan pesisir untuk dijadikan tempat tinggal mereka hanya mendapatkan izin lokasi saja bukan "Alas Hak" atau Surat Keterangan Riwayat Pemilikan Penguasaan Penggunaan Tanah yang diterbitkan Kantor Desa ataupun hak atas tanah dalam bentuk Hak Milik, Hak Guna Bangunan ataupun Hak Pakai. Demikian halnya pada Peraturan Menteri Agraria dan Tata Ruang/Kepala Badan Pertanahan Nasional Nomor 17 Tahun 2016 tentang Penataan Pertanahan di Wilayah Pesisir dan Pulau-Pulau Kecil, yang mensyaratkan bahwa hak atas tanah hanya dapat diberikan pada bangunan yang merupakan tempat tinggal masyarakat adat atau anggota masyarakat yang secara turuntemurun sudah bertempat tinggal ditempat tersebut. Maka seharusnya pihak Kantor Pertanahan Kabupaten Anambas menambahkan pesyaratan untuk mendapatkan hak atas tanah agar tidak diterbitkan kepada semua pihak yang memanfaatkan kawasan pesisir untuk dijadikan permukiman pelantar.

Sehingga dapat disimpulkan bahwa status penguasaan tanah di kawasan pantai dan pesisir yang dijadikan permukiman (rumah pelantar) di Kabupaten Kepulauan Anambas tidak memiliki dasar hukum yang kuat karena peruntukannya dan proses pemberian izinnya tidak sesuai dengan peraturan yang ada. Hal ini terjadi karena pejabat yang berwenang baik Kepala Desa maupun pihak Kantor Pertanahan Kabupaten Kepulauan Anambas dalam menerbitkan surat bukti penguasaan atas tanah tidak sesuai dengan peraturan perundang - undangan yang terkait, disamping itu juga masih kurangnya sosialisasi dari pemerintah pusat maupun daerah dan juga keterbatasan ilmu pengetahuan penduduk sekitar mengenai penguasaan tanah.

Mengenai Rencana Zonasi Wilayah Pesisir dan Pulau-Pulau Kecil (RZWP3K) di
Kabupaten Kepulauan Anambas belum mencapai tahap finalisasi sehingga Dewan Perwakilan Rakyat Daerah (DPRD) Provinsi Kepulauan Riau meminta pemerintah Provinsi Kepri segera untuk menyelesaikan persoalan yang menyangkut Rancangan Peraturan Daerah Rencana Zonasi Wilayah Pesisir dan Pulau-pulau Kecil di Provinsi Kepulauan Riau hal ini mengingat bahwa pentingnya keberadaan pengaturan peraturan daerah tersebut. ${ }^{12}$

Pemerintah Provinsi Kepulauan Riau seharusnya segera menyelesaikan Rencana Zonasi wilayah pesisir dan pulau-pulau kecil (RZWP3K) yang diperuntukkan bagi masyarakat yang membangun permukiman dan juga yang membudidayakan ikan serta sumber daya laut lainnya. Hal ini penting karena untuk menetapkan batas batas terhadap setiap kegiatan pemanfaatan ruang di wilayah pesisir yakni untuk permukiman, kegiatan sosial ekonomi, kegiatan konservasi maupun pemanfaatan ekonomi terhadap sumber daya laut. Sehingga akan tercipta keseimbangan fungsi pemanfaat dan perlindungan wilayah pesisir dan mengoptimalkan pemanfaatan ruang sesuai zona kegiatannya dan tidak terjadinya pemborosan pemanfaatan ruang ataupun ketidaksesuaian zona kegiatan pemanfaatan wilayah pesisir sehingga hal ini akan meminimalisir terjadinya penurunan kualitas wilayah pesisir. Serta dapat diketahui secara jelas mengenai kegiatan yang boleh dilakukan dan tidak boleh dilakukan serta kegiatan yang hanya dapat dilakukan setelah memperoleh izin, Karena RZWP3K ini menjadi acuan dan syarat sebelum diterbitkannya Izin Lokasi Perairan untuk masyarakat di Desa Pesisir Timur yang termasuk masyarakat lokal atau masyarakat tradisional yang memanfaatkan kawasan pantai dan pesisir untuk dijadikan rumah pelantar.

12 Diskominfo Kepri, Rencana Zonasi Wilayah Pesisir dan Pulau-Pulau Kecil (RZWP3K) Provinsi Kepulauan Riau, $30 \quad$ Juli 2019, https://kepriprov.go.id// Diakses Pada Tanggal 8 Januari 2020, Pukul 19.50 WIB. 


\section{B. Status Dari Permukiman Rumah Pelantar Di Kawasan Pantai dan Pesisir yang Menjamin Kepastian Hukum}

Tingkat pertumbuhan penduduk yang meningkat setiap tahunnya mengakibatkan kebutuhan akan tempat tinggal juga tentunya meningkat karena tempat tinggal menjadi kebutuhan dasar dari manusia yang digunakan untuk berlindung baik dari iklim atau makhluk hidup lainnya dan juga untuk melakukan aktivitas kehidupannya. Jumlah penduduk yang berada di Kabupaten Kepulauan Anambas berdasarkan proyeksi penduduk tahun 2017 sebanyak 41.412 jiwa dengan penduduk terbanyak ada di Kecamatan Palmatak. Dibandingkan dengan proyeksi jumlah penduduk tahun 2016, penduduk Kepulauan Anambas mengalami pertumbuhan sebesar $1,20 \%$.

Kabupaten Kepulauan Anambas, memiliki wilayah lautan yang lebih luas dibandingkan dengan daratannya sesuai dengan data yakni luas wilayah daratan $590,14 \mathrm{Km}^{2}$ dan luas lautan $46.033,81 \mathrm{Km}^{2}$. Sehingga hal ini berdampak terhadap kurangnya ketersediaan tanah yang dapat di bangun tempat tinggal di wilayah daratan. Oleh karena itu membuat penduduk mencari alternatif lain untuk memenuhi kebutuhan mereka yaitu dengan memanfaatkan kawasan pesisir dan pantai untuk dibangun tempat tinggal yang kemudian menjadi permukiman di atas air atau masyarakat Anambas menyebutnya Permukiman Rumah Pelantar.

Pembangunan permukiman di kawasan pantai dan pesisir dinilai membahayakan ekosistem dari pantai dan pesisir tersebut hal ini disebabkan karena padatnya bangunan dan kurangnya pengelolaan sanitasi dan sampah menyebabkan tercemarnya air laut oleh limbah rumah tangga. Jika semakin banyaknya permukiman yang dibangun di kawasan pantai dan pesisir lalu kian memasuki wilayah laut dan tak terkontrol, tentunya hal ini juga dapat merusak ekosistem terumbu karang dan ikan yang tergantung pada terumbu karang.

Berdasarkan Peraturan Daerah Kabupaten Kepulauan Anambas Nomor 3 Tahun 2013 Tentang Rencana Tata Ruang Wilayah Kabupaten Kepulauan Anambas Tahun 2011-2031 yang selanjutnya disebut RTRW Kabupaten Kepulauan Anambas, Kawasan Permukiman adalah bagian dari lingkungan hidup di luar kawasan lindung baik berupa kawasan pesisir, perkotaan maupun kawasan perdesaan yang berfungsi sebagai lingkungan tempat tinggal atau lingkungan hunian dan tempat kegiatan yang mendukung perikehidupan dan penghidupan. Sesuai dengan RTRW Kabupaten Kepulauan Anambas bahwa kebijakan dan stategi untuk pengoptimalisasian pengembangan kawasan pesisir dan pulau - pulau kecil dilakukan dengan mengoptimalkan pola ruang kawasan pesisir sebagai kawasan permukiman, pelabuhan dan industri dan kawasan lindung sehingga tetap terjadi keseimbangan pengembangan kawasan. Sehingga berdasarkan zonasi penetapan fungsi kawasan pesisir pada RTRW Kabupaten Kepulauan Anambas, Desa Pesisir Timur sudah sesuai karena terletak di kawasan pesisir yang memang diperuntukkan untuk permukiman penduduk.

Status penguasaan tanah dari Permukiman (Rumah Pelantar) Di Kawasan Pantai Dan Pesisir yang dimiliki oleh masyarakat Desa Pesisir Timur, Kecamatan Siantan tidak berdasarkan peraturan yang berlaku, sehingga menjadi tidak sah dan tidak memiliki dasar hukum yang jelas maka tidak ada kepastian hukum terhadap alas hak yang diterbitkan oleh Kepala Desa di permukiman rumah pelantar. Hal tersebut dapat menimbulkan sengketa di kemudian hari, karena tidak adanya kekuatan hukum terhadap alas hak tersebut sehingga sewaktu 
- waktu dapat saja terjadi penggusuran terhadap permukiman (rumah pelantar) masyarakat Desa Pesisir Timur yang hanya berdasarkan "Alas Hak" yang diberikan oleh Kepala Desa dan tidak memiliki dasar yang kuat untuk tetap mempertahankan penguasaan tanah di wilayah pesisir tersebut.

Permukiman rumah pelantar di Desa Pesisir Timur dikatakan tidak memiliki dasar hukum yang kuat karena pelaksanaannya bertentangan dengan peraturan perundang - undangan yang berlaku, seharusnya yang dapat menjamin kepastian hukum adalah bagi masyarakat lokal dan masyarakat tradisional yang tidak turun temurun Desa Pesisir Timur yang memanfaatkan ruang di wilayah pesisir secara menetap berdomisili di pesisir paling singkat 5 tahun berturut-turut atau paling singkat 10 tahun tidak berturut-turut maka harus memiliki izin lokasi sesuai pada ketentuan Pasal 16 Undang-Undang Nomor 1 Tahun 2014 tentang Perubahan atas Undang-Undang Nomor 27 Tahun 2007 tentang Pengelolaan Wilayah Pesisir dan Pulau-Pulau Kecil jo Pasal 45 ayat (1) Peraturan Menteri Kelautan Dan Perikanan Republik Indonesia Nomor 24/PermenKp/2019 Tentang Tata Cara Pemberian Izin Lokasi Perairan Dan Izin Pengelolaan Perairan Di Wilayah Pesisir Dan PulauPulau Kecil.

Status penguasaan berupa "alas hak" yang dimiliki oleh masyarakat Desa Pesisir Timur bahwasanya tidak ada jaminan keamanan dan kepastian hukum akan keberadaan permukiman rumah pelantar bagi masyarakat yang tidak memiliki izin lokasi. Hal ini disebabkan oleh kurangnya pengetahuan masyarakat akan hukum khususnya di bidang pertanahan dan juga budaya hukum masyarakat di Desa Pesisir yang menganggap bahwa "Alas Hak" atau Surat Keterangan Riwayat Pemilikan Penguasaan Penggunaan Tanah yang diterbitkan oleh Kepala Desa sudah sesuai dengan hukum yang berlaku karena pada praktiknya hal ini sudah dilakukan sejak lama dan semua masyarakat yang memanfaatkan kawasan pantai dan pesisir pasti memiliki "Alas Hak" tersebut.

Pada Pasal 6 ayat (2) Peraturan Menteri Agraria dan Tata Ruang/Kepala Badan Pertanahan Nasional Nomor 17 Tahun 2016 tentang Penataan Pertanahan di Wilayah Pesisir dan Pulau-Pulau Kecil:

"Selain syarat yang diatur dalam peraturan perundang-undangan mengenai pemberian Hak Atas Tanah, pemberian Hak Atas Tanah di Wilayah Pesisir juga harus memenuhi syarat:

a. Peruntukannya sesuai dengan rencana tata ruang wilayah provinsi/ kabupaten/kota, atau rencana zonasi Wilayah Pesisir

b. mendapatkan rekomendasi dari pemerintah provinsi/kabupten/kota dalam hal belum diatur mengenai peruntukan tanah dalam RTRW

c. memenuhi ketentuan perizinan dan instansi terkait."

Berdasarkan ketentuan tersebut maka seharusnya Kepala Desa di Desa Pesisir Timur tidak memberikan suatu "Alas Hak" kepada masyarakat yang ingin memanfaatkan kawasan pesisir dan pantai untuk tempat tinggal, Hal yang seharusnya dilakukan adalah dengan memberi rekomendasi kepada penduduk yang hendak memanfaatkan kawasan pesisir untuk tempat tinggal yakni rumah pelantar yang kemudian ingin membuat bukti penguasaannya tersebut lalu akan disampaikan kepada Bupati lalu kemudian jika sudah memenuhi syarat bahwa masyarakat tersebut merupakan masyarakat lokal maka akan diberikan izin lokasi hal ini sesuai dengan Peraturan Menteri Kelautan Dan Perikanan Republik Indonesia Nomor 24/Permen-Kp/2019 Tentang Tata Cara Pemberian Izin Lokasi Perairan Dan Izin Pengelolaan Perairan Di Wilayah Pesisir Dan Pulau-Pulau Kecil.

Pemberian atau penetapan alas hak terhadap penguasaan tanah bagi mereka yang memanfaatkan kawasan pantai dan pesisir sebagai upaya pemberian kepastian hukum dapat juga dilakukan dengan melakukan pendaftaran tanah yang 
merupakan tujuan dari UUPA yang tercantum pada Pasal 19 ayat (1) UUPA yang kemudian diatur lanjut dalam Peraturan Pemerintah Nomor 24 Tahun 1997 Tentang Pendaftaran Tanah. Pada dasarnya salah satu tujuan pendaftaran tanah adalah untuk memberikan kepastian hukum dan perlindungan hukum kepada pemegang hak atas suatu bidang tanah, satuan rumah susun dan hak-hak lain yang terdaftar agar dengan mudah dapat membuktikan dirinya sebagai pemegang hak yang bersangkutan.

Pendaftaran Tanah dalam rangka Recht Kadaster yang bertujuan memberikan kepastian hukum dan perlindungan hukum kepada pemegang hak atas tanah, dengan alat bukti yang dihasilkan pada akhir proses pendaftaran tersebut berupa buku tanah dan sertifikat yang terdiri dari buku tanah dan surat ukur.

Disamping itu Pemerintah telah melakukan upaya untuk dapat memberikan kepastian hukum bagi masyarakat yang memanfaatkan kawasan pantai dan pesisir sebagai tempat tinggal dengan menerbitkan Peraturan Menteri Agraria dan Tata Ruang/Kepala Badan Pertanahan Nasional Nomor 17 Tahun 2016 tentang Penataan Pertanahan di Wilayah Pesisir dan PulauPulau Kecil. Dalam peraturan tersebut di atur bahwa masyarakat adat ataupun masyarakat lokal yang sudah tinggal turun temurun dan memiliki tempat tinggal di kawasan pantai dan pesisir maka dapat diberikan hak atas tanah.

Sehingga agar terciptanya kepastian hukum bagi permukiman pelantar yang dimiliki masyarakat adat ataupun masyarakat lokal yang sudah tinggal turun temurun dan memiliki tempat tinggal di kawasan pantai dan pesisir tersebut harus dilakukan upaya terlebih dahulu dari pihak Kepala Desa di Desa Pesisir Timur yang berperan sebagai penghubung yakni dengan memberi rekomendasi kepada masyarakat untuk mengurus permohonan hak atas tanah kepada Kantor Pertanahan di Kabupaten
Kepulauan Anambas, lalu pihak yang berwenang dalam hal ini Kantor Pertanahan harus menerbitkan hak atas tanah sesuai dengan persyaratan yang sudah ada dalam Pasal 5 Peraturan Menteri Agraria dan Tata Ruang/Kepala Badan Pertanahan Nasional Nomor 17 Tahun 2016 tentang Penataan Pertanahan di Wilayah Pesisir dan PulauPulau Kecil. Jika hal ini dilakukan maka diharapkan seluruh masyarakat di kawasan pantai dan pesisir di Kabupaten Kepulauan Anambas menguasai tanahnya secara sah sesuai dengan peraturan perundang undangan yang berlaku dengan diberikannya suatu surat alas hak atas tanah yang sesuai.

Bagi masyarakat Desa Pesisir Timur yang sudah memiliki Alas Hak atau Surat Keterangan Riwayat Pemilikan Penguasaan Penggunaan Tanah yang diterbitkan oleh Kepala Desa untuk dijadikan permukiman pelantar maka sebaiknya dilakukan perubahan terhadap bentuk penguasaannya sesuai dengan peraturan perundang undangan yang berlaku yang dibantu oleh petugas yang berwenang. Dan bagi masyarakat yang sudah memiliki hak atas tanah yang berbentuk surat berjangka sesuai dengan penerbitan yang dilakukan oleh Kantor Pertanahan Kabupaten Anambas, selain mereka memiliki kewajiban untuk memelihara tanah tersebut dan mereka juga memiliki hak untuk dapat menikmati tempat tinggal tersebut sehingga terhadap masyarakat ini tetap harus mendapatkan perlindungan hukum dengan menetapkan jangka waktu dalam memanfaatkan hak atas tanah yang telah diberikan kepadanya.

Pengetahuan akan status dan pembatasan penguasaan tanah di wilayah pesisir dan pantai menjadi penting dalam pengelolaan wilayah pesisir dan pantai secara berkelanjutan. Namun, pengelolaan dan penataan permukiman juga menjadi tanggung jawab pemerintah daerah maupun pemerintah pusat untuk melakukan penertiban dan menangani permasalahan 
pembangunan tempat tinggal di kawasan pantai dan pesisir yang tentunya juga memberikan kepastian hukum mengenai status penguasaan tanahnya.

\section{KESIMPULAN}

Status penguasaan tanah yang dimiliki oleh penduduk Desa Pesisir Timur ini tidak sesuai dengan peraturan perundang - undangan yang berlaku. Karena berdasarkan pada Undang - undang Nomor 1 Tahun 2014 jo Peraturan Menteri Kelautan Dan Perikanan Republik Indonesia Nomor 24/Permen-Kp/2019 seharusnya terhadap masyarakat lokal, masyarakat tradisional atau pendatang yang tidak turun temurun dalam memanfaatkan kawasan pantai dan pesisir untuk dijadikan tempat tinggal mereka hanya mendapatkan izin lokasi saja bukan hak atas tanah dalam bentuk, Hak Milik, Hak Guna Bangunan ataupun Hak Pakai. Demikian halnya pada Peraturan Menteri Agraria dan Tata Ruang/Kepala Badan Pertanahan Nasional Nomor 17 Tahun 2016 tentang Penataan Pertanahan di Wilayah Pesisir dan PulauPulau Kecil, yang mensyaratkan bahwa hak atas tanah hanya dapat diberikan pada bangunan yang merupakan tempat tinggal masyarakat adat atau anggota masyarakat yang secara turun-temurun sudah bertempat tinggal ditempat tersebut. Hak atas tanah tersebut diterbitkan oleh Kantor Pertanahan Kabupaten Kepulauan Anambas sesuai dengan peraturan perundang - undangan yang berlaku.

\section{DAFTAR PUSTAKA}

\section{A. Buku}

Ali Achmad Chomzah, Hukum Pertanahan, Jakarta : Prestasi Pustaka,2002.

Boedi Harsono, Hukum Agraria Indonesia (Sejarah pembentukan Undangundang Pokok Agraria, Isi dan Pelaksanaannya), Jilid I, Cetakan keduabelas, Jakarta : Djambatan, 2003.
Ronny Hanityo Soemitro, Metodologi Penelitian Hukum dan Jurimetri, Jakarta : Ghalia Indonesia, 2000.

Soerjono Soekanto dan Sri Mamuji, Penelitian Hukum Normatif (Suatu Tinjauan Singkat),

Jakarta: Rajawali Pers, 2001.

Sunaryati Hartono, Penelitian Hukum di Indonesia Pada Akhir Abad Ke - 20, Bandung: Alumni, 2006.

\section{B. Peraturan Perundang - Undangan}

Undang - Undang Dasar Negara Republik Indonesia Tahun 1945.

Undang-Undang Republik Indonesia Nomor 5 Tahun 1960 tentang Peraturan

Dasar Pokok-Pokok Agraria.

Undang-Undang Nomor 26 Tahun 2007 tentang Penataan Ruang.

Undang-Undang Republik Indonesia Nomor 32 Tahun 2009 tentang Perlindungan dan Pengelolaan Lingkungan Hidup.

Undang - Undang Nomor 1 Tahun 2011 tentang Perumahan dan Kawasan Pemukiman.

Undang-Undang Nomor 1 Tahun 2014 tentang Perubahan atas UndangUndang Nomor 27 Tahun 2007 tentang Pengelolaan Wilayah Pesisir dan Pulau-Pulau Kecil.

Peraturan Menteri Agraria dan Tata Ruang Kepala Badan Pertanahan Nasional Republik Indonesia Nomor 17 Tahun 2016 tentang Penataan Pertanahan di Wilayah Pesisir dan Pulau-pulau Kecil.

Peraturan Menteri Kelautan Dan Perikanan Republik Indonesia Nomor 24/Permen-Kp/2019 Tentang Tata Cara Pemberian Izin Lokasi Perairan Dan Izin Pengelolaan Perairan Di Wilayah Pesisir Dan Pulau-Pulau Kecil

Peraturan Daerah Kabupaten Kepulauan Anambas Nomor 3 Tahun 2013 Tentang Rencana Tata Ruang Wilayah Kabupaten Kepulauan Anambas Tahun 20112031. 


\section{Sumber Lain}

Wawancara dengan Kepala Sub Bidang

Pengembangan, Evaluasi Dan

Pelaporan Di Badan Penelitian

Pengembangan Dan Perencanaan

Daerah Kapubaten Kepulauan

Anambas, Bapak Ika Rio Saputra,

Pada tanggal 11 Mei 2019.

Wawancara dengan Kepala Desa Pesisir

Timur Kecamatan Siantan

Kabupaten Kepulauan Anambas,

Bapak Sabli, Pada Tanggal 12

September 2019.

Wawancara dengan Seksi Hubungan

Hukum Pertanahan Di Kantor

Pertanahan Kabupaten Kepulauan

Anambas, Bapak Deko, Pada

Tanggal 8 Oktober 2019.

Diskominfo Kepri, Rencana Zonasi Wilayah Pesisir dan Pulau-Pulau Kecil (RZWP3K) Provinsi Kepulauan Riau, $30 \quad$ Juli 2019, https://kepriprov.go.id/ Diakses Pada Tanggal 8 Januari 2020, Pukul 19.50

WIB 